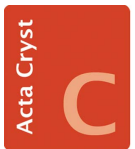

STRUCTURAL

CHEMISTRY

ISSN 2053-2296

Received 24 March 2020

Accepted 19 June 2020

Edited by H. Uekusa, Tokyo Institute of Technology, Japan

Keywords: magnesium; carbonate; chloride; hydrate; synchrotron; twinning; crystal structure.

CCDC reference: 2010753

Supporting information: this article has supporting information at journals.iucr.org/c

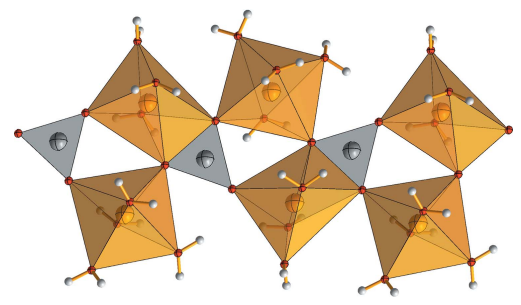

OPEN $\odot$ ACCESS

\section{Crystal structure and characterization of magnesium carbonate chloride heptahydrate}

\author{
Christine Rincke, ${ }^{a *}$ Horst Schmidt, ${ }^{a}$ Gernot Buth ${ }^{b}$ and Wolfgang Voigt ${ }^{a}$ \\ a Institute of Inorganic Chemistry, TU Bergakademie Freiberg, Leipziger Strasse 29, D-09599 Freiberg, Germany, and \\ b Institute for Photon Science and Synchrotron Radiation (IPS), Karlsruhe Institute of Technology (KIT), Hermann-von- \\ Helmholtz-Platz 1, D-76344 Eggenstein-Leopoldshafen, Germany. *Correspondence e-mail: \\ christine.rincke@chemie.tu-freiberg.de
}

$\mathrm{MgCO}_{3} \cdot \mathrm{MgCl}_{2} \cdot 7 \mathrm{H}_{2} \mathrm{O}$ is the only known neutral magnesium carbonate containing chloride ions at ambient conditions. According to the literature, only small and twinned crystals of this double salt could be synthesised in a concentrated solution of $\mathrm{MgCl}_{2}$. For the crystal structure solution, single-crystal diffraction was carried out at a synchrotron radiation source. The monoclinic crystal structure (space group $\mathrm{Cc}$ ) exhibits double chains of $\mathrm{MgO}$ octahedra linked by corners, connected by carbonate units and water molecules. The chloride ions are positioned between these double chains parallel to the (100) plane. Dry $\mathrm{MgCO}_{3} \cdot \mathrm{MgCl}_{2} \cdot 7 \mathrm{H}_{2} \mathrm{O}$ decomposes in the air to chlorartinite, $\mathrm{Mg}_{2}(\mathrm{OH}) \mathrm{Cl}\left(\mathrm{CO}_{3}\right) \cdot n \mathrm{H}_{2} \mathrm{O}$ ( $n=2$ or 3$)$. This work includes an extensive characterization of the title compound by powder X-ray diffraction, thermal analysis, SEM and vibrational spectroscopy.

\section{Introduction}

In the context of $\mathrm{CO}_{2}$ research, the interactions of $\mathrm{CO}_{2}$ with salts and brine solutions are of great interest. Therefore, the system $\mathrm{MgCl}_{2}-\mathrm{MgCO}_{3}-\mathrm{H}_{2} \mathrm{O}-\mathrm{CO}_{2}$ has been investigated. The only nonbasic salt containing carbonate and chloride ions is $\mathrm{MgCO}_{3} \cdot \mathrm{MgCl}_{2} \cdot 7 \mathrm{H}_{2} \mathrm{O}$ (Rincke, 2018).

The formation conditions of $\mathrm{MgCO}_{3} \cdot \mathrm{MgCl}_{2} \cdot 7 \mathrm{H}_{2} \mathrm{O}$ were described for the first time by Gloss (1937) and Walter-Levy (1937). It can be synthesized at room temperature by adding $\mathrm{MgCO}_{3} \cdot 3 \mathrm{H}_{2} \mathrm{O}$ to a highly concentrated solution of magnesium chloride saturated with $\mathrm{CO}_{2}$ (Gloss, 1937; Schmidt, 1960).

Within the scope of outbursts of $\mathrm{CO}_{2}$ in potash mines, $\mathrm{MgCO}_{3} \cdot \mathrm{MgCl}_{2} \cdot 7 \mathrm{H}_{2} \mathrm{O}$ was discussed as a storage compound for $\mathrm{CO}_{2}$ in the 1960s (Schmidt, 1960; Serowy, 1963; Serowy \& Liebmann, 1964; Schmittler, 1964; D’Ans, 1967). This salt forms needle-like crystals, which are only stable in concentrated $\mathrm{MgCl}_{2}$ solution (Moshkina \& Yaroslavtseva, 1970). It decomposes immediately when it is washed with water. When it was stored in air, basic carbonate was formed (Gloss, 1937).

Schmittler (1964) concluded from a powder X-ray diffraction (PXRD) pattern of $\mathrm{MgCO}_{3} \cdot \mathrm{MgCl}_{2} \cdot 7 \mathrm{H}_{2} \mathrm{O}$ that its crystal structure exhibits a $C$-centred monoclinic lattice with parameters $a=13.27(0), b=11.30(8), c=9.22(7) \AA$ and $\beta=$ $118.2(6)^{\circ}$. Due to the low scattering power and the small size of the crystals, a crystal structure analysis of single crystals was not possible until now. Our own investigations should provide a better comprehension of the synthesis of $\mathrm{MgCO}_{3} \cdot \mathrm{MgCl}_{2}$. $7 \mathrm{H}_{2} \mathrm{O}$ and provide a more detailed characterization, including a crystal structure analysis. 


\section{Experimental}

\subsection{Synthesis and crystallization}

The synthesis of $\mathrm{MgCO}_{3} \cdot \mathrm{MgCl}_{2} \cdot 7 \mathrm{H}_{2} \mathrm{O}$ is based on the information of Schmidt (1960). MgO (1 g, Magnesia M2329, p.a.) was added to $200 \mathrm{~g}$ of an aqueous solution of $\mathrm{MgCl}_{2}(5.5$ molal, Fluka, $\geq 98 \%$ ). The suspension was stirred for $30 \mathrm{~min}$. Afterwards, the undissolved $\mathrm{MgO}$ was filtered off. $\mathrm{CO}_{2}$ was bubbled through the stirred solution for $24 \mathrm{~h}$ at room temperature. The product was filtered off for further characterization.

\subsection{Single-crystal diffraction}

Data were collected on beamline SCD at the KIT Synchrotron Radiation Source using a Stoe IPDS diffractometer with monochromated radiation of $\lambda=0.8000 \AA$. A crystal of $\mathrm{MgCO}_{3} \cdot \mathrm{MgCl}_{2} \cdot 7 \mathrm{H}_{2} \mathrm{O}$ was recovered from a droplet of its mother liquor and mounted rapidly in the cold $(150 \mathrm{~K})$ stream of nitrogen gas of the diffractometer.

\subsection{Powder X-ray diffraction (PXRD)}

PXRD patterns were taken for phase identification with a laboratory Bruker D8 Discover powder diffractometer in Bragg-Brentano set up ( $\mathrm{Cu} K \alpha_{1}$ radiation, Vantec 1 detector). The samples were prepared as flat plates and measured at room temperature.

\subsection{Thermal analysis}

The thermal analysis was performed with a TG/DTA 220 instrument from Seiko Instruments (reference substance: $\mathrm{Al}_{2} \mathrm{O}_{3}$, open platinum crucible; argon flow: $300 \mathrm{ml} \mathrm{min}^{-1}$;
Table 1

Experimental details.

\begin{tabular}{|c|c|}
\hline \multicolumn{2}{|l|}{ Crystal data } \\
\hline Chemical formula & $\mathrm{MgCO}_{3} \cdot \mathrm{MgCl}_{2} \cdot 7 \mathrm{H}_{2} \mathrm{O}$ \\
\hline$M_{\mathrm{r}}$ & 305.64 \\
\hline Crystal system, space group & Monoclinic, $C c$ \\
\hline Temperature $(\mathrm{K})$ & 150 \\
\hline$a, b, c(\AA)$ & $13.368(5), 11.262(5), 9.266(4)$ \\
\hline$\beta\left(^{\circ}\right)$ & $118.83(3)$ \\
\hline$V\left(\AA^{3}\right)$ & $1222.0(9)$ \\
\hline$Z$ & 4 \\
\hline Radiation type & Synchrotron, $\lambda=0.8000 \AA$ \\
\hline$\mu\left(\mathrm{mm}^{-1}\right)$ & 0.93 \\
\hline Crystal size $(\mathrm{mm})$ & $0.13 \times 0.07 \times 0.01 \times 0.02$ (radius) \\
\hline \multicolumn{2}{|l|}{ Data collection } \\
\hline Diffractometer & Stoe IPDS II \\
\hline Absorption correction & For a sphere (Coppens, 1970) \\
\hline $\begin{array}{l}\text { No. of measured, independent and } \\
\text { observed }[I>2 \sigma(I)] \text { reflections }\end{array}$ & $8746,6975,5476$ \\
\hline$R_{\text {int }}$ & 0.0613 \\
\hline$\theta_{\max }\left({ }^{\circ}\right)$ & 26.7 \\
\hline$(\sin \theta / \lambda)_{\max }\left(\AA^{-1}\right)$ & 0.561 \\
\hline \multicolumn{2}{|l|}{ Refinement } \\
\hline$R\left[F^{2}>2 \sigma\left(F^{2}\right)\right], w R\left(F^{2}\right), S$ & $0.053,0.161,1.12$ \\
\hline No. of reflections & 4791 \\
\hline No. of parameters & 179 \\
\hline No. of restraints & 22 \\
\hline $\mathrm{H}$-atom treatment & Only $\mathrm{H}$-atom coordinates refined \\
\hline$\Delta \rho_{\max }, \Delta \rho_{\min }\left(\mathrm{e} \AA^{-3}\right)$ & $0.36,-0.43$ \\
\hline Absolute structure & $\begin{array}{l}\text { Flack } x \text { determined using } 647 \\
\quad \text { quotients }\left[\left(I^{+}\right)-\left(I^{-}\right)\right] / \\
{\left[\left(I^{+}\right)+\left(I^{-}\right)\right](\text {Parsons } \text { et al. }, 2013)}\end{array}$ \\
\hline Absolute structure parameter & $0.43(13)$ \\
\hline
\end{tabular}

Computer programs: $X$-AREA (Stoe \& Cie, 2015), X-RED (Stoe \& Cie, 2015), SHELXS97 (Sheldrick, 2008), SHELXL2016 (Sheldrick, 2015), DIAMOND (Brandenburg, 2017) and publCIF (Westrip, 2010).

heating rate: $5 \mathrm{~K} \mathrm{~min}^{-1}$, prior period $30 \mathrm{~min}$ at $298.15 \mathrm{~K}$ in an argon flow).

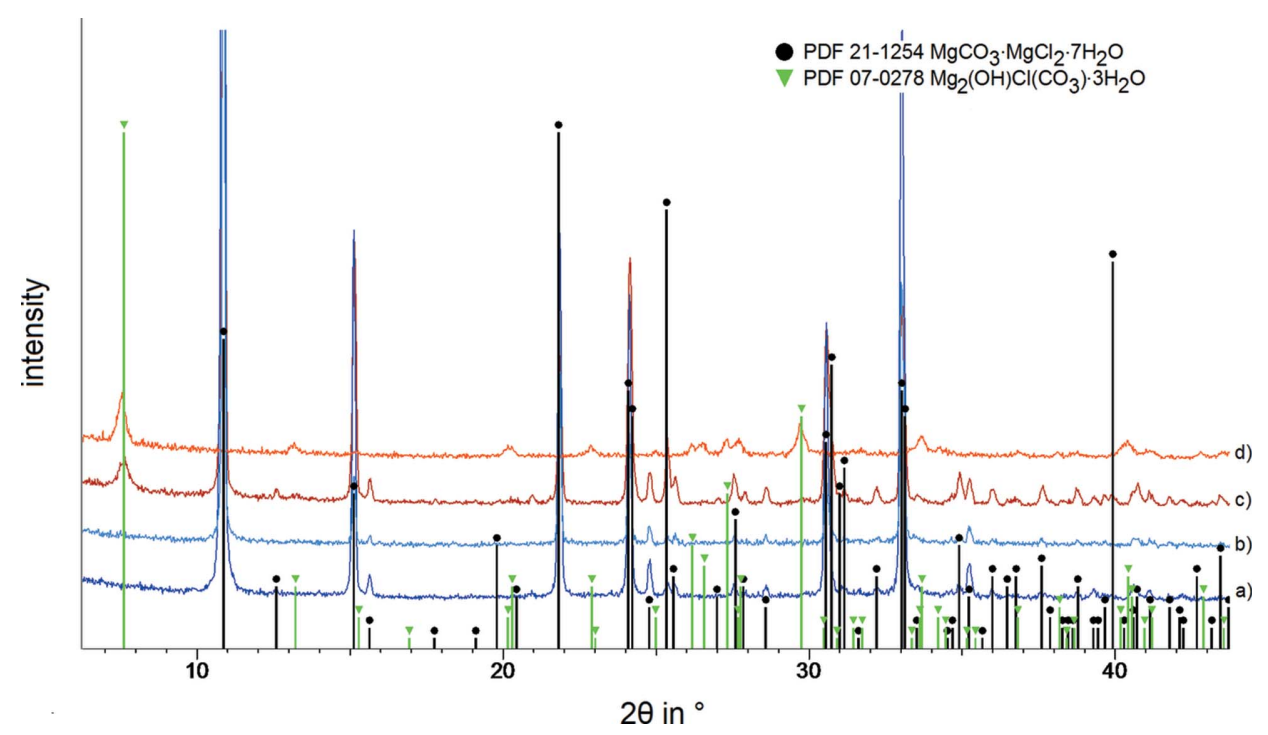

Figure 1

Powder XRD patterns of $\mathrm{MgCO}_{3} \cdot \mathrm{MgCl}_{2} \cdot 7 \mathrm{H}_{2} \mathrm{O}$ under ambient conditions ( $\mathrm{Cu} K \alpha_{1}$ radiation) for $(a)$ the unwashed product immediately after the synthesis, $(b)$ the unwashed product stored in the air after 19 months, $(c)$ the product washed with ethanol after storage in the air for $10 \mathrm{~d}$ and $(d)$ the product washed with ethanol after storage in the air for 19 months. Reference data: $\mathrm{MgCO}_{3} \cdot \mathrm{MgCl}_{2} \cdot 7 \mathrm{H}_{2} \mathrm{O}(\mathrm{PDF} 21-1254)$ and $\mathrm{Mg} 2(\mathrm{OH}) \mathrm{Cl}(\mathrm{CO} 3) \cdot 3 \mathrm{H}_{2} \mathrm{O}$ (PDF 07-0278). 


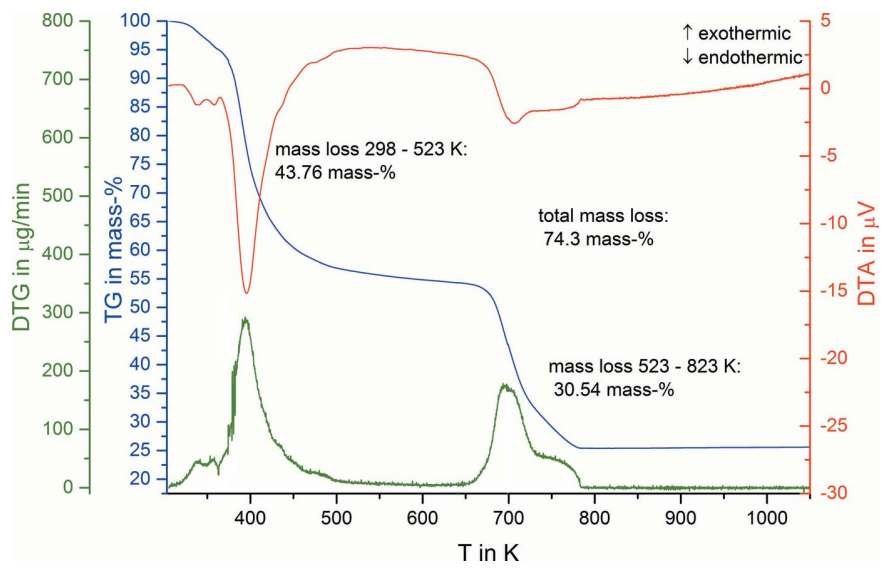

Figure 2

Thermal analysis of $\mathrm{MgCO}_{3} \cdot \mathrm{MgCl}_{2} \cdot 7 \mathrm{H}_{2} \mathrm{O}$.

\subsection{Scanning electron microscopy (SEM)}

The SEM images were recorded with a TESCAN Vega 5130 $\mathrm{SB}$ instrument $(20 \mathrm{kV}$ accelerating voltage). The sample was coated with gold.

\subsection{Vibrational spectroscopy}

For the FT-IR spectrum, a Thermo Scientific Nicolet 380 FTIR spectrometer (spectral resolution: $6 \mathrm{~cm}^{-1}, 256$ scans per measurement) with $\mathrm{KBr}$ blanks was used.

The Raman spectrum was recorded shortly after synthesis with a Bruker RFS100/S FT spectrometer at room temperature (Nd/YAG-laser, wavelength of the laser: $1064 \mathrm{~nm})$.

\subsection{Refinement}

Crystal data, data collection and structure refinement details are given in Table 1. Due to the small crystals and their low scattering power, the crystal structure solution was carried out by single-crystal diffraction at a synchrotron radiation source. The quality of the crystals affected the measured data set with the effect that only reflections to $\sin \theta_{\max } / \lambda=0.56 \AA^{-1}$ could be considered for the structure refinement. The crystal structure was solved by direct methods. The resulting structure solution exhibits a chemically reasonable atomic arrangement, distances, angles and displacement parameters.

$\mathrm{H}$ atoms were placed in the positions indexed by difference Fourier maps and their $U_{\text {iso }}$ values were set at $1.2 U_{\text {eq }}(\mathrm{O})$ using a riding-model approximation.

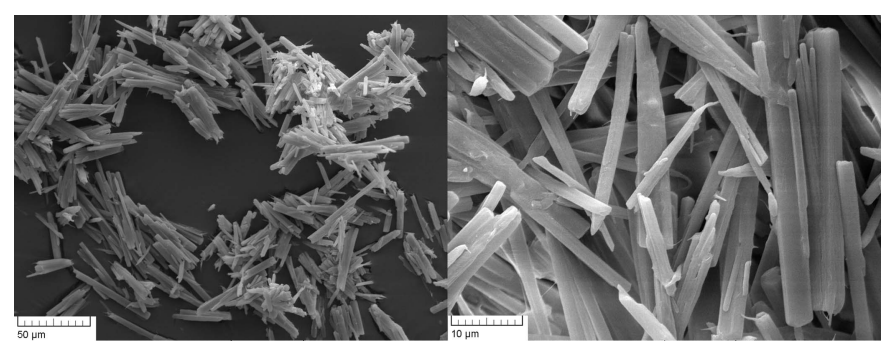

Figure 3

SEM images of $\mathrm{MgCO}_{3} \cdot \mathrm{MgCl}_{2} \cdot 7 \mathrm{H}_{2} \mathrm{O}$, with the crystals exhibiting twinning or even further intergrowth.
Table 2

Assignment of the IR and Raman bands of $\mathrm{MgCO}_{3} \cdot \mathrm{MgCl}_{2} \cdot 7 \mathrm{H}_{2} \mathrm{O}$.

\begin{tabular}{lll}
\hline IR & Raman & $\begin{array}{l}\text { Assignment (Coleyshaw } \\
\text { et al., 2003) }\end{array}$ \\
\hline 3407,3240 & 3386,3250 & $\nu(\mathrm{OH})_{\mathrm{W}}$ \\
1635 & 1660 & $\delta(\mathrm{OH})_{\mathrm{W}}$ \\
$1550,1449,1401$ & 1544 & $\nu_{\text {as }}(\mathrm{CO})$ \\
1114 & 1111 & $v_{s}(\mathrm{CO})$ \\
845 & 794 & $\gamma(\mathrm{CO})$ \\
620 & 599 & $\delta_{\text {as }}(\mathrm{CO})$ \\
457 & $403,227,181,154,124$ & lattice vibrations \\
\hline
\end{tabular}

Notes: $v=$ valence vibration, $\delta=$ deformation vibration (in the plane), $\gamma=$ deformation vibration out of the plane, $\mathrm{W}=$ water, $\mathrm{s}=$ symmetric and as $=$ asymmetric.

The crystal exhibits nonmerohedral twinning. The matrix that relates the individual diffraction pattern was determined as $(101.38,0-10,00-1)$. The reflections of both domains were integrated (number of reflections in domain 1: 2829; domain 2: 3505; overlaid: 641; major twin component fraction: $56.45 \%)$.

\section{Results and discussion}

\subsection{Characterization of magnesium carbonate chloride} heptahydrate

The characterization of the unwashed product with PXRD is in accordance with the reference pattern PDF 21-1254 for $\mathrm{MgCO}_{3} \cdot \mathrm{MgCl}_{2} \cdot 7 \mathrm{H}_{2} \mathrm{O}$ (Schmittler, 1964). The filtered product was stored in a sealed vessel. After 19 months, the powder pattern remained constant, i.e. the product did not alter. If the product was washed with ethanol and stored in the air, decomposition to chlorartinite $\left[\mathrm{Mg}_{2}(\mathrm{OH}) \mathrm{Cl}\left(\mathrm{CO}_{3}\right) \cdot 3 \mathrm{H}_{2} \mathrm{O}\right]$ begins within a few days (Fig. 1). This observation confirms the information of Gloss (1937).

The thermal decomposition of $\mathrm{MgCO}_{3} \cdot \mathrm{MgCl}_{2} \cdot 7 \mathrm{H}_{2} \mathrm{O}$ starts as early as the heating begins and shows two main steps (Fig. 2). $\mathrm{H}_{2} \mathrm{O}, \mathrm{CO}_{2}$ and $\mathrm{HCl}$ are evaporated off. This is in accordance with the observation of Serowy \& Liebmann (1964). A precise assignment of the stepwise mass loss is not possible. The characterization of the residue with PXRD at $573 \mathrm{~K}$ exhibits the presence of a mixture of basic magnesium carbonates, i.e. hydromagnesite $\left[\mathrm{Mg}_{5}\left(\mathrm{CO}_{3}\right)_{4}(\mathrm{OH})_{2} \cdot 4 \mathrm{H}_{2} \mathrm{O}\right]$ and amorphous phases. At $803 \mathrm{~K}$ the decomposition is complete and only $\mathrm{MgO}$ remains in the residue. The observed mass loss of 74.3 (1)\% confirms the theoretical mass loss of $73.6 \%$.

The SEM images of $\mathrm{MgCO}_{3} \cdot \mathrm{MgCl}_{2} \cdot 7 \mathrm{H}_{2} \mathrm{O}$ show thin needles $(50 \times 5 \mu \mathrm{m})$, which are twinned or even more intergrown (Fig. 3). Numerous crystallization experiments with the aim of obtaining larger crystals were not successful.

The FT-IR (Fig. 4) and Raman spectra (Fig. 5) of $\mathrm{MgCO}_{3} \cdot \mathrm{MgCl}_{2} \cdot 7 \mathrm{H}_{2} \mathrm{O}$ confirm the absence of hydroxide ions in the crystal structure, because there are no bands above $3500 \mathrm{~cm}^{-1}$ as in chlorartinite, $\mathrm{Mg}_{2}(\mathrm{OH}) \mathrm{Cl}\left(\mathrm{CO}_{3}\right) \cdot 3 \mathrm{H}_{2} \mathrm{O}$ (Vergasova et al., 1998). The assignment of the bands was concluded from a comparison with the vibrational spectra of other neutral magnesium carbonates and chlorartinite (Coleyshaw et al., 2003; Vergasova et al., 1998) (Table 2). 


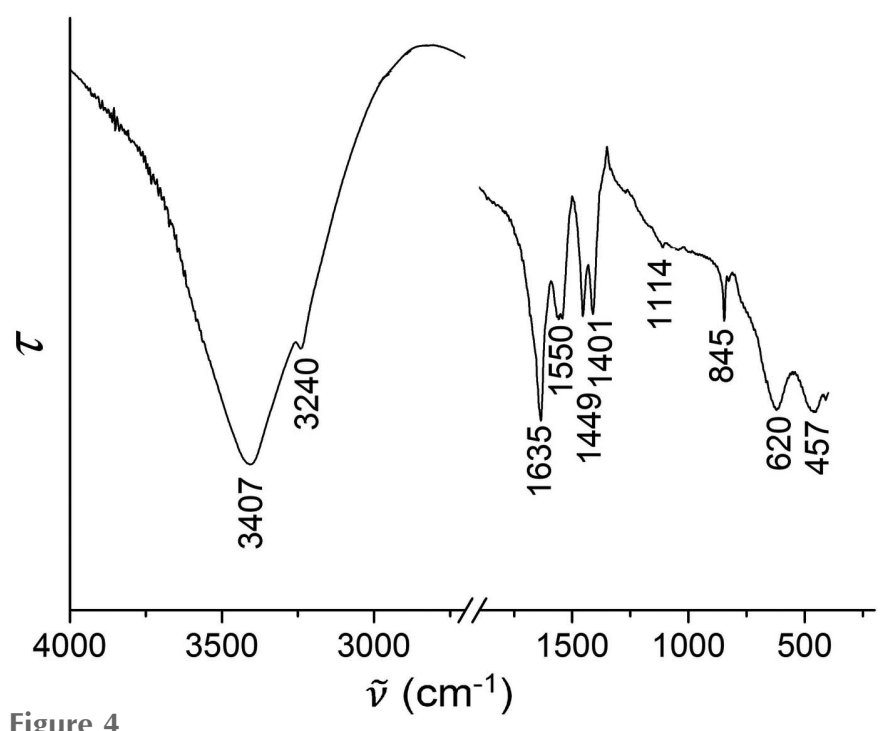

IR spectrum of $\mathrm{MgCO}_{3} \cdot \mathrm{MgCl}_{2} \cdot 7 \mathrm{H}_{2} \mathrm{O}$ under ambient conditions.

\subsection{Crystal structure of magnesium carbonate chloride heptahydrate}

The monoclinic crystal structure of $\mathrm{MgCO}_{3} \cdot \mathrm{MgCl}_{2} \cdot 7 \mathrm{H}_{2} \mathrm{O}$ with the space group $C c$ and the lattice parameters published by Schmittler (1964) were confirmed. There are two distinguishable magnesium ions. $\mathrm{Mg} 1$ is coordinated by three water molecules and two carbonate anions. One carbonate acts as a monodentate ligand via atom $\mathrm{O} 9$ and the other as a bidentate ligand via atoms $\mathrm{O} 2$ and $\mathrm{O} 6$. The octahedra of $\mathrm{Mg} 2$ are formed by four water molecules and two carbonate units which are connected to the magnesium ion in a monodentate manner via atoms $\mathrm{O} 2$ and $\mathrm{O} 6$ (Fig. 6). The corner-linked $\mathrm{Mg}-\mathrm{O}$ octahedra are arranged in a zigzag manner and together with the carbonate units form double chains parallel to the (100) plane (Fig. 7).

All the carbonate units are crystallographically equivalent and exhibit a $C_{s}$ geometry, because they are planar, but the $\mathrm{C}-\mathrm{O}$ bonds have different lengths. Each carbonate unit is coordinated by three magnesium ions: monodentate to $\mathrm{Mg} 1$,

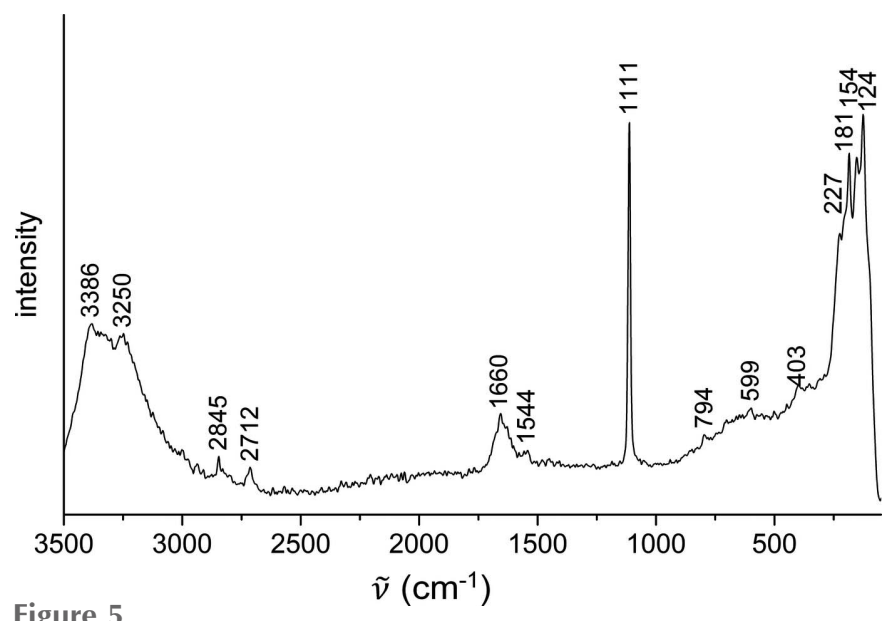

Figure 5

Raman spectrum of $\mathrm{MgCO}_{3} \cdot \mathrm{MgCl}_{2} \cdot 7 \mathrm{H}_{2} \mathrm{O}$ under ambient conditions.

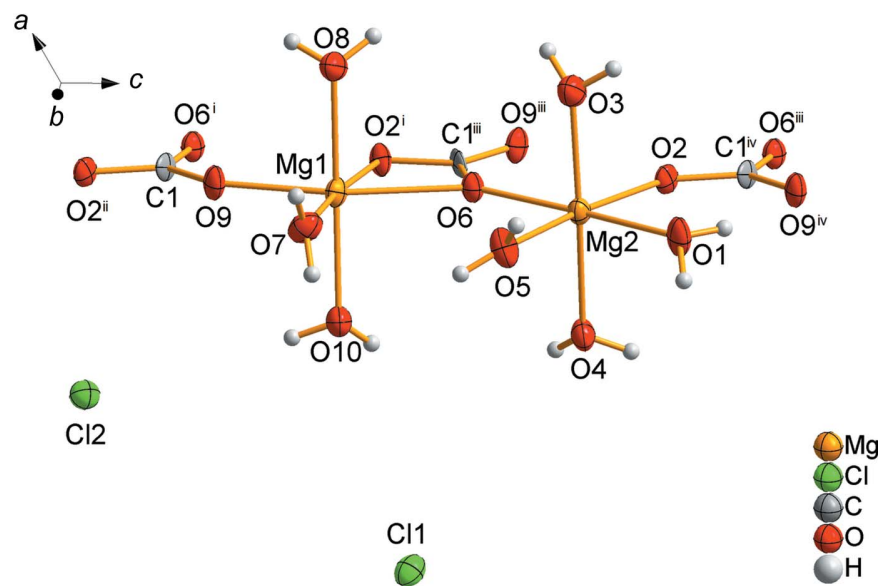

Figure 6

The asymmetric unit and coordination units of $\mathrm{MgCO}_{3} \cdot \mathrm{MgCl}_{2} \cdot 7 \mathrm{H}_{2} \mathrm{O}$ [symmetry codes: (i) $x,-y, z-\frac{1}{2}$; (ii) $x, y, z-1$; (iii) $x,-y, z+\frac{1}{2}$; (iv) $x, y$, $z+1]$.

bidentate to $\mathrm{Mg}^{\mathrm{i}}$ and monodentate to $\mathrm{Mg}^{2}{ }^{\text {ii }}$ (see Fig. 6 for symmetry codes). In addition, the carbonate units stabilize the double chains (Fig. 7).

Between the double chains, which are arranged in a zigzaglike stacking order parallel to the (001) plane, are located the chloride ions $\mathrm{Cl} 1$ and $\mathrm{Cl} 2$ (Fig. 8). The positions of atoms $\mathrm{H} 1 \mathrm{~A}$ and $\mathrm{H} 3 B$ are fixed by short hydrogen bonds to atoms $\mathrm{O}^{\text {iv }}$ and $\mathrm{O} 4^{\mathrm{vi}}$, and the other $\mathrm{H}$ atoms by interactions with the chloride ions (Table 3 and Fig. 9). As a consequence, a three-dimensional network is formed.

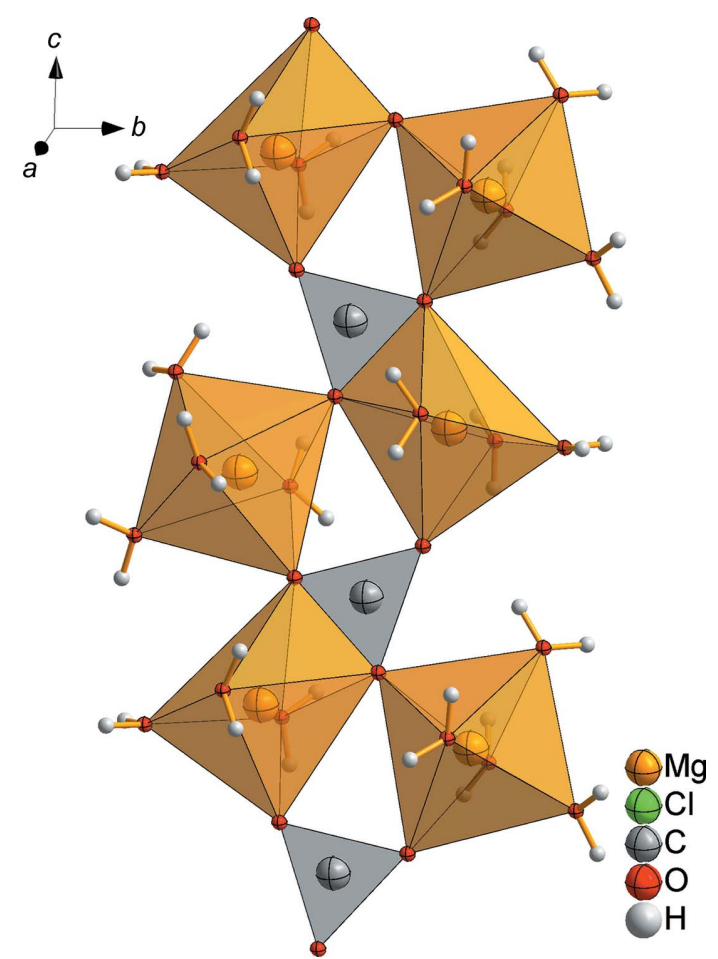

Figure 7

The characteristic structural motif in $\mathrm{MgCO}_{3} \cdot \mathrm{MgCl}_{2} \cdot 7 \mathrm{H}_{2} \mathrm{O}$, showing the double chain of $\mathrm{MgO}$ octahedra linked by corners and carbonate units parallel to the (100) plane. 
Table 3

Hydrogen-bond geometry $\left(\AA,^{\circ}\right)$.

\begin{tabular}{|c|c|c|c|c|}
\hline$D-\mathrm{H} \cdots A$ & $D-\mathrm{H}$ & $\mathrm{H} \cdots A$ & $D \cdots A$ & $D-\mathrm{H} \cdots A$ \\
\hline $\mathrm{O} 1-\mathrm{H} 1 A \cdots \mathrm{O} 9^{\mathrm{iv}}$ & $0.82(3)$ & $1.94(6)$ & $2.688(14)$ & $153(13)$ \\
\hline $\mathrm{O} 1-\mathrm{H} 1 B \cdots \mathrm{Cl} 2^{\mathrm{iv}}$ & $0.82(3)$ & $2.38(4)$ & 3.186 (11) & 167 (12) \\
\hline $\mathrm{O} 3-\mathrm{H} 3 A \cdots \mathrm{Cl} 2^{\mathrm{v}}$ & $0.82(3)$ & $2.32(3)$ & 3.135 (11) & $174(17)$ \\
\hline $\mathrm{O} 3-\mathrm{H} 3 B \cdots \mathrm{O} 4^{\mathrm{vi}}$ & $0.82(3)$ & $2.10(11)$ & $2.796(13)$ & 143 (17) \\
\hline $\mathrm{O} 4-\mathrm{H} 4 A \cdots \mathrm{Cl} 1^{\mathrm{vii}}$ & $0.82(3)$ & $2.36(3)$ & $3.176(10)$ & $171(14)$ \\
\hline $\mathrm{O} 4-\mathrm{H} 4 B \cdots \mathrm{Cl} 1^{\text {viii }}$ & $0.82(3)$ & $2.49(7)$ & $3.251(10)$ & 155 (13) \\
\hline $\mathrm{O} 5-\mathrm{H} 5 A \cdots \mathrm{Cl} 2^{\text {viii }}$ & $0.82(3)$ & $2.45(7)$ & $3.222(11)$ & $157(16)$ \\
\hline $\mathrm{O} 5-\mathrm{H} 5 B \cdots \mathrm{Cl} 1^{\mathrm{ix}}$ & $0.81(3)$ & $2.54(6)$ & 3.327 (11) & $164(17)$ \\
\hline $\mathrm{O} 7-\mathrm{H} 7 A \cdots \mathrm{Cl} 2^{\text {viii }}$ & $0.82(3)$ & $2.42(6)$ & 3.212 (11) & $163(16)$ \\
\hline $\mathrm{O} 7-\mathrm{H} 7 B \cdots \mathrm{Cl}^{\mathrm{x}}$ & $0.82(3)$ & $2.30(4)$ & 3.111 (11) & 169 (16) \\
\hline $\mathrm{O} 8-\mathrm{H} 8 A \cdots \mathrm{Cl}^{\mathrm{vi}}$ & $0.82(3)$ & $2.46(5)$ & $3.254(10)$ & $163(11)$ \\
\hline $\mathrm{O} 8-\mathrm{H} 8 B \cdots \mathrm{Cl}^{\mathrm{v}}$ & $0.82(3)$ & $2.41(3)$ & $3.233(10)$ & 178 (11) \\
\hline $\mathrm{O} 10-\mathrm{H} 10 A \cdots \mathrm{Cl} 1^{\mathrm{vii}}$ & $0.82(3)$ & $2.34(5)$ & $3.146(10)$ & $166(15)$ \\
\hline $\mathrm{O} 10-\mathrm{H} 10 B \cdots \mathrm{Cl} 1^{\mathrm{xi}}$ & $0.82(3)$ & $2.67(7)$ & $3.424(10)$ & 154 (12) \\
\hline
\end{tabular}

Symmetry codes: (iv) $x, y, z+1$; (v) $x+\frac{1}{2}, y-\frac{1}{2}, z+1$; (vi) $x+\frac{1}{2},-y+\frac{1}{2}, z+\frac{1}{2}$; (vii) $x, y-1$, $z$; (viii) $x,-y+1, z+\frac{1}{2}$; (ix) $x+\frac{1}{2},-y+\frac{3}{2}, z+\frac{1}{2}$; (x) $x+\frac{1}{2}, y-\frac{1}{2}, z$; (xi) $x,-y+1, z-\frac{1}{2}$.

The structural motifs of such double chains are similar in $\mathrm{MgCO}_{3} \cdot \mathrm{MgCl}_{2} \cdot 7 \mathrm{H}_{2} \mathrm{O}$ and $\mathrm{MgCO}_{3} \cdot 3 \mathrm{H}_{2} \mathrm{O}$ (Giester et al., 2000), but in contrast to $\mathrm{MgCO}_{3} \cdot 3 \mathrm{H}_{2} \mathrm{O}$ in $\mathrm{MgCO}_{3} \cdot \mathrm{MgCl}_{2} \cdot 7 \mathrm{H}_{2} \mathrm{O}$, only two of three carbonate units and three and four water molecules instead of two water molecules are linked to each $\mathrm{Mg}$ atom. Furthermore, no free water molecules are positioned between these double chains in $\mathrm{MgCO}_{3} \cdot \mathrm{MgCl}_{2} \cdot 7 \mathrm{H}_{2} \mathrm{O}$. The crystal structures of other neutral magnesium carbonates, e.g. $\mathrm{MgCO}_{3} \cdot 5 \mathrm{H}_{2} \mathrm{O}, \mathrm{MgCO}_{3} \cdot 6 \mathrm{H}_{2} \mathrm{O}$ and the chloride-containing magnesium carbonates $\mathrm{Mg}_{2}(\mathrm{OH}) \mathrm{Cl}\left(\mathrm{CO}_{3}\right) \cdot 2 \mathrm{H}_{2} \mathrm{O}$ (chlorartinite) and $\mathrm{Mg}_{2}(\mathrm{OH}) \mathrm{Cl}\left(\mathrm{CO}_{3}\right) \cdot \mathrm{H}_{2} \mathrm{O}$ (dehydrated clorartinite), do not exhibit such double chains (Liu et al., 1990; Rincke et al., 2020; Sugimoto et al., 2006, 2007). Therefore, the crystal structure of $\mathrm{MgCO}_{3} \cdot \mathrm{MgCl}_{2} \cdot 7 \mathrm{H}_{2} \mathrm{O}$ is unique.

\section{Acknowledgements}

The award of synchrotron beamtime at KIT Synchrotron Radiation Source, Karlsruhe, Germany, is gratefully acknowledged.

\section{References}

Brandenburg, K. (2017). DIAMOND. Crystal Impact GbR, Bonn, Germany.

Coleyshaw, E. E., Crump, G. \& Griffith, W. P. (2003). Spectrochim. Acta A Mol. Biomol. Spectrosc. 59, 2231-2239.

Coppens, P. (1970). Crystallographic Computing, edited by F. R. Ahmed, S. R. Hall \& C. P. Huber, pp. 255-270. Copenhagen: Munksgaard.

D'Ans, J. (1967). Kali und Steinsalz, 4, 396-401.

Giester, G., Lengauer, C. L. \& Rieck, B. (2000). Mineral. Petrol. 70, 153-163.

Gloss, G. (1937). Dissertation. Friedrich-Wilhelms-University of Berlin, Germany.

Liu, B., Zhou, X., Cui, X. \& Tang, J. (1990). Sci. China Ser. B, 33, 1350-1356.

Moshkina, I. A. \& Yaroslavtseva, L. M. (1970). Zh. Neorg. Khim. 15, 3345-3350.

Parsons, S., Flack, H. D. \& Wagner, T. (2013). Acta Cryst. B69, 249259.

Rincke, C. (2018). Dissertation. TU Bergakademie Freiberg, Germany.

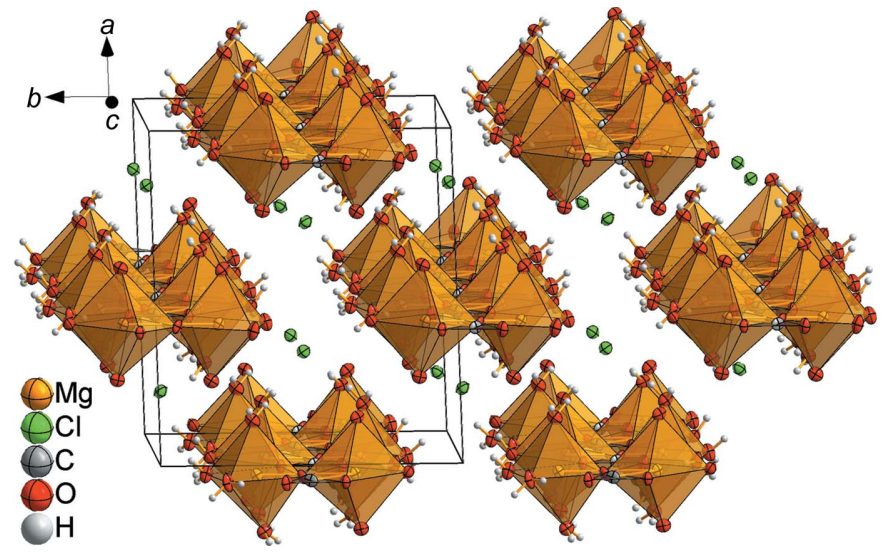

Figure 8

Excerpt of the crystal structure of $\mathrm{MgCO}_{3} \cdot \mathrm{MgCl}_{2} \cdot 7 \mathrm{H}_{2} \mathrm{O}$, showing the zigzag-like stacking order of the double chains and the chloride ions between them.

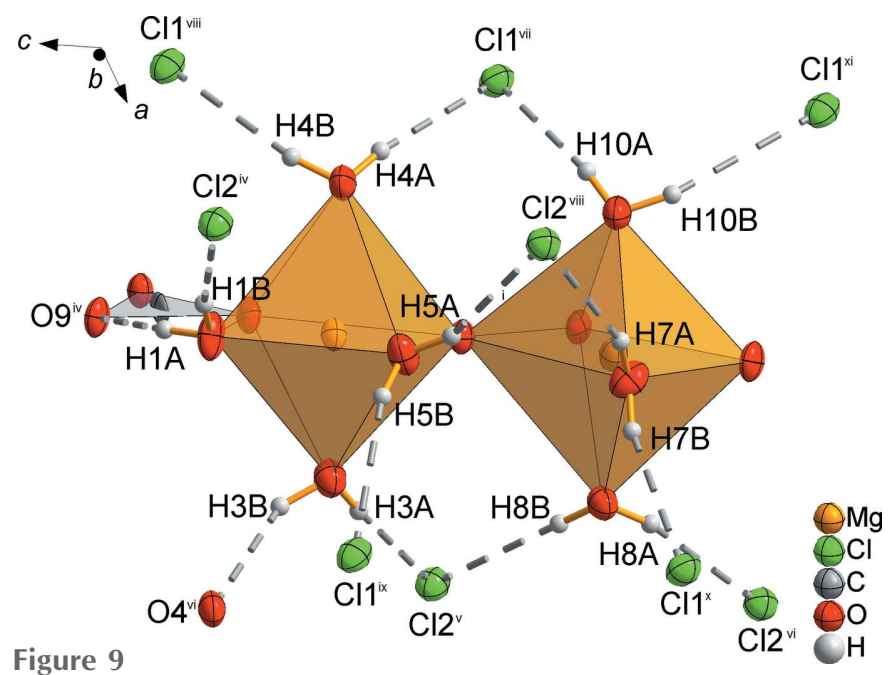

Excerpt of the crystal structure of $\mathrm{MgCO}_{3} \cdot \mathrm{MgCl}_{2} \cdot 7 \mathrm{H}_{2} \mathrm{O}$, showing the hydrogen-bond interactions of the $\mathrm{H}$ atoms with chloride ions (dashed lines) [symmetry codes: (iv) $x, y, z+1$; (v) $x+\frac{1}{2}, y-\frac{1}{2}, z+1$; (vi) $x+\frac{1}{2}$, $-y+\frac{1}{2}, z+\frac{1}{2}$; (vii) $x, y-1, z$; (viii) $x,-y+1, z+\frac{1}{2}$; (ix) $x+\frac{1}{2},-y+\frac{3}{2}, z+\frac{1}{2}$; (x) $\left.x+\frac{1}{2}, y-\frac{1}{2}, z ;(\mathrm{xi}) x,-y+1, z-\frac{1}{2}\right]$.

Rincke, C., Schmidt, H. \& Voigt, W. (2020). Acta Cryst. C76, 244-249. Schmidt, E. (1960). Bergakademie, 12, 693-697.

Schmittler, H. (1964). Deut. Akad. Wiss. 6, 644-648.

Serowy, F. (1963). Freiberger Forschungshefte A, 267, 405-419.

Serowy, F. \& Liebmann, G. (1964). Wissenschaftl. Zeitschrift der Technischen Hochschule für Chemie 'Carl Schorlemmer' LeunaMerseburg, 6, 338-342.

Sheldrick, G. M. (2008). Acta Cryst. A64, 112-122.

Sheldrick, G. M. (2015). Acta Cryst. C71, 3-8.

Stoe \& Cie (2015). $X$-AREA and $X$-RED32. Stoe \& Cie, Darmstadt, Germany.

Sugimoto, K., Dinnebier, R. E. \& Schlecht, T. (2006). J. Appl. Cryst. 39, 739-744.

Sugimoto, K., Dinnebier, R. E. \& Schlecht, T. (2007). Powder Diff. 22(1), 739-744.

Vergasova, L. P., Filation, S. K., Serafimova, E. K. \& Sergeeva, S. V. (1998). Zapiski Vserossiiskogo Mineralogicheskogo Obshchestva, 127, 55-59.

Walter-Levy, L. (1937). Compt. Rend. 205, 1405-1407.

Westrip, S. P. (2010). J. Appl. Cryst. 43, 920-925. 


\section{supporting information}

Acta Cryst. (2020). C76, 741-745 [https://doi.org/10.1107/S2053229620008153]

\section{Crystal structure and characterization of magnesium carbonate chloride} heptahydrate

\section{Christine Rincke, Horst Schmidt, Gernot Buth and Wolfgang Voigt}

Computing details

Data collection: $X$-AREA (Stoe \& Cie, 2015); cell refinement: $X$-AREA (Stoe \& Cie, 2015); data reduction: $X$-RED (Stoe \& Cie, 2015); program(s) used to solve structure: SHELXS97 (Sheldrick, 2008); program(s) used to refine structure:

SHELXL2016 (Sheldrick, 2015); molecular graphics: DIAMOND (Brandenburg, 2017); software used to prepare material for publication: publCIF (Westrip, 2010).

Magnesium carbonate chloride heptahydrate

\section{Crystal data}

$\mathrm{MgCO}_{3} \cdot \mathrm{MgCl}_{2} \cdot 7 \mathrm{H}_{2} \mathrm{O}$

$M_{r}=305.64$

Monoclinic, $C c$

$a=13.368(5) \AA$

$b=11.262(5) \AA$

$c=9.266(4) \AA$

$\beta=118.83(3)^{\circ}$

$V=1222.0(9) \AA^{3}$

$Z=4$

Data collection

Stoe IPDS II diffractometer

Radiation source: synchrotron rotation method scans

Absorption correction: for a sphere

(Coppens, 1970)

8746 measured reflections

\section{Refinement}

Refinement on $F^{2}$

Least-squares matrix: full

$R\left[F^{2}>2 \sigma\left(F^{2}\right)\right]=0.053$

$w R\left(F^{2}\right)=0.161$

$S=1.12$

4791 reflections

179 parameters

22 restraints

Primary atom site location: structure-invariant direct methods

Hydrogen site location: difference Fourier map
$F(000)=632$

$D_{\mathrm{x}}=1.661 \mathrm{Mg} \mathrm{m}^{-3}$

Synchrotron radiation, $\lambda=0.8000 \AA$

Cell parameters from 4192 reflections

$\theta=2.7-29.5^{\circ}$

$\mu=0.93 \mathrm{~mm}^{-1}$

$T=150 \mathrm{~K}$

Needle, colourless

$0.13 \times 0.07 \times 0.01 \times 0.02$ (radius) $\mathrm{mm}$

6975 independent reflections

5476 reflections with $I>2 \sigma(I)$

$R_{\text {int }}=0.061$

$\theta_{\text {max }}=26.7^{\circ}, \theta_{\min }=3.3^{\circ}$

$h=-14 \rightarrow 14$

$k=-12 \rightarrow 12$

$l=-10 \rightarrow 10$

Only $\mathrm{H}$-atom coordinates refined

$w=1 /\left[\sigma^{2}\left(F_{0}^{2}\right)+(0.094 P)^{2}\right]$

where $P=\left(F_{\mathrm{o}}{ }^{2}+2 F_{\mathrm{c}}{ }^{2}\right) / 3$

$(\Delta / \sigma)_{\max }<0.001$

$\Delta \rho_{\max }=0.36 \mathrm{e} \AA^{-3}$

$\Delta \rho_{\min }=-0.43$ e $\AA^{-3}$

Absolute structure: Flack $x$ determined using 647 quotients $[(\mathrm{I}+)-(\mathrm{I}-)] /[(\mathrm{I}+)+(\mathrm{I}-)]$ (Parsons et al., 2013)

Absolute structure parameter: 0.43 (13) 


\section{Special details}

Geometry. All esds (except the esd in the dihedral angle between two 1.s. planes) are estimated using the full covariance matrix. The cell esds are taken into account individually in the estimation of esds in distances, angles and torsion angles; correlations between esds in cell parameters are only used when they are defined by crystal symmetry. An approximate (isotropic) treatment of cell esds is used for estimating esds involving l.s. planes.

Refinement. Refined as a 2-component twin

Fractional atomic coordinates and isotropic or equivalent isotropic displacement parameters $\left(\AA^{2}\right)$

\begin{tabular}{lllll}
\hline & $x$ & $y$ & $z$ & $U_{\text {iso }} * / U_{\text {eq }}$ \\
\hline Mg1 & $0.4801(4)$ & $0.1376(3)$ & $0.5771(6)$ & $0.0178(9)$ \\
Mg2 & $0.4708(3)$ & $0.1837(4)$ & $0.9931(5)$ & $0.0182(10)$ \\
C11 & $0.1825(3)$ & $0.9715(3)$ & $0.5763(4)$ & $0.0262(9)$ \\
C12 & $0.2944(3)$ & $0.5078(3)$ & $0.0497(4)$ & $0.0249(8)$ \\
C1 & $0.4795(10)$ & $0.0190(12)$ & $0.2714(13)$ & $0.017(3)$ \\
O1 & $0.4661(9)$ & $0.2884(9)$ & $1.1718(12)$ & $0.028(2)$ \\
H1B & $0.419(11)$ & $0.341(10)$ & $1.152(18)$ & $0.034^{*}$ \\
H1A & $0.468(13)$ & $0.250(11)$ & $1.247(14)$ & $0.034^{*}$ \\
O2 & $0.4771(7)$ & $0.0395(8)$ & $1.1333(10)$ & $0.0196(19)$ \\
O3 & $0.6440(9)$ & $0.1968(9)$ & $1.1050(12)$ & $0.028(2)$ \\
H3B & $0.680(13)$ & $0.211(16)$ & $1.203(6)$ & $0.034^{*}$ \\
H3A & $0.688(12)$ & $0.153(13)$ & $1.09(2)$ & $0.034^{*}$ \\
O4 & $0.2896(8)$ & $0.1586(9)$ & $0.8686(11)$ & $0.025(2)$ \\
H4B & $0.264(12)$ & $0.148(13)$ & $0.932(14)$ & $0.029^{*}$ \\
H4A & $0.255(12)$ & $0.112(11)$ & $0.792(12)$ & $0.029^{*}$ \\
O5 & $0.4634(9)$ & $0.3447(9)$ & $0.8750(12)$ & $0.029(2)$ \\
H5A & $0.433(12)$ & $0.371(12)$ & $0.781(7)$ & $0.034^{*}$ \\
H5B & $0.509(12)$ & $0.395(10)$ & $0.933(13)$ & $0.034^{*}$ \\
O6 & $0.4774(8)$ & $0.0931(8)$ & $0.8055(12)$ & $0.0184(19)$ \\
O7 & $0.4802(9)$ & $0.3153(9)$ & $0.5418(13)$ & $0.028(2)$ \\
H7A & $0.427(8)$ & $0.361(9)$ & $0.52(2)$ & $0.034^{*}$ \\
H7B & $0.536(7)$ & $0.358(10)$ & $0.57(2)$ & $0.034^{*}$ \\
O8 & $0.6599(8)$ & $0.1449(9)$ & $0.7010(12)$ & $0.025(2)$ \\
H8B & $0.694(12)$ & $0.111(12)$ & $0.790(8)$ & $0.029^{*}$ \\
H8A & $0.686(11)$ & $0.116(12)$ & $0.645(12)$ & $0.029^{*}$ \\
O9 & $0.4820(8)$ & $0.1034(8)$ & $0.3651(11)$ & $0.022(2)$ \\
O10 & $0.3036(8)$ & $0.1571(9)$ & $0.4583(11)$ & $0.024(2)$ \\
H10B & $0.278(11)$ & $0.150(13)$ & $0.359(5)$ & $0.029^{*}$ \\
H10A & $0.262(10)$ & $0.117(12)$ & $0.481(14)$ & $0.029^{*}$ \\
& & & &
\end{tabular}

Atomic displacement parameters $\left(\AA^{2}\right)$

\begin{tabular}{lllllll}
\hline & $U^{11}$ & $U^{22}$ & $U^{33}$ & $U^{12}$ & $U^{13}$ & $U^{23}$ \\
\hline $\mathrm{Mg} 1$ & $0.023(2)$ & $0.017(2)$ & $0.0156(18)$ & $-0.0018(19)$ & $0.0114(15)$ & $-0.004(2)$ \\
$\mathrm{Mg} 2$ & $0.022(2)$ & $0.019(2)$ & $0.0152(18)$ & $0.0026(17)$ & $0.0102(16)$ & $0.0000(17)$ \\
$\mathrm{C} 11$ & $0.0248(16)$ & $0.0273(19)$ & $0.0302(17)$ & $-0.0052(14)$ & $0.0162(14)$ & $-0.0031(15)$ \\
$\mathrm{C} 2$ & $0.0242(15)$ & $0.0255(16)$ & $0.0257(15)$ & $0.0023(14)$ & $0.0126(12)$ & $0.0018(14)$ \\
$\mathrm{C} 1$ & $0.021(6)$ & $0.023(8)$ & $0.010(7)$ & $0.001(5)$ & $0.008(6)$ & $-0.009(6)$
\end{tabular}


supporting information

\begin{tabular}{lllllll} 
O1 & $0.048(6)$ & $0.021(5)$ & $0.024(5)$ & $0.008(4)$ & $0.023(5)$ & $0.009(4)$ \\
O2 & $0.027(5)$ & $0.017(5)$ & $0.017(4)$ & $0.005(4)$ & $0.013(4)$ & $-0.003(4)$ \\
O3 & $0.030(6)$ & $0.032(6)$ & $0.023(5)$ & $0.005(4)$ & $0.013(5)$ & $-0.001(4)$ \\
O4 & $0.028(5)$ & $0.030(5)$ & $0.017(5)$ & $-0.002(4)$ & $0.012(4)$ & $0.001(4)$ \\
O5 & $0.040(6)$ & $0.023(5)$ & $0.020(5)$ & $-0.006(4)$ & $0.013(4)$ & $-0.001(4)$ \\
O6 & $0.025(5)$ & $0.016(5)$ & $0.017(4)$ & $0.000(4)$ & $0.012(4)$ & $0.002(4)$ \\
O7 & $0.030(5)$ & $0.022(5)$ & $0.038(7)$ & $0.006(4)$ & $0.021(5)$ & $0.004(4)$ \\
O8 & $0.024(5)$ & $0.029(5)$ & $0.020(5)$ & $0.003(4)$ & $0.010(4)$ & $-0.003(4)$ \\
O9 & $0.034(6)$ & $0.018(5)$ & $0.020(5)$ & $0.002(4)$ & $0.018(4)$ & $0.005(4)$ \\
O10 & $0.025(5)$ & $0.029(6)$ & $0.019(5)$ & $0.001(4)$ & $0.012(4)$ & $0.002(4)$ \\
\hline
\end{tabular}

Geometric parameters $\left(\stackrel{A}{ }{ }^{\circ}\right)$

\begin{tabular}{|c|c|c|c|}
\hline $\mathrm{Mg} 1-\mathrm{O} 9$ & $2.014(10)$ & $\mathrm{Mg} 2-\mathrm{O} 2$ & $2.055(10)$ \\
\hline $\mathrm{Mg} 1-\mathrm{O} 7$ & $2.028(11)$ & $\mathrm{Mg} 2-\mathrm{O} 1$ & $2.058(11)$ \\
\hline $\mathrm{Mg} 1-\mathrm{O} 2^{\mathrm{i}}$ & $2.066(9)$ & $\mathrm{Mg} 2-\mathrm{O} 5$ & $2.095(11)$ \\
\hline $\mathrm{Mg} 1-\mathrm{O} 10$ & $2.079(11)$ & $\mathrm{Mg} 2-\mathrm{O} 4$ & $2.140(11)$ \\
\hline $\mathrm{Mg} 1-\mathrm{O} 8$ & $2.107(11)$ & $\mathrm{C} 1-\mathrm{O} 9$ & $1.277(15)$ \\
\hline $\mathrm{Mg} 1-\mathrm{O} 6$ & $2.192(10)$ & $\mathrm{C} 1-\mathrm{O} 2^{\mathrm{ii}}$ & $1.285(15)$ \\
\hline $\mathrm{Mg} 2-\mathrm{O} 3$ & $2.036(11)$ & $\mathrm{C} 1-\mathrm{O}^{\mathrm{i}}$ & $1.305(17)$ \\
\hline $\mathrm{Mg} 2-\mathrm{O} 6$ & $2.054(11)$ & & \\
\hline $\mathrm{O} 9-\mathrm{Mg} 1-\mathrm{O} 7$ & $91.7(4)$ & $\mathrm{O} 3-\mathrm{Mg} 2-\mathrm{O} 1$ & $91.0(5)$ \\
\hline $\mathrm{O} 9-\mathrm{Mg} 1-\mathrm{O} 2^{\mathrm{i}}$ & $94.2(4)$ & $\mathrm{O} 6-\mathrm{Mg} 2-\mathrm{O} 1$ & $174.8(5)$ \\
\hline $\mathrm{O} 7-\mathrm{Mg} 1-\mathrm{O} 2^{\mathrm{i}}$ & $174.1(5)$ & $\mathrm{O} 2-\mathrm{Mg} 2-\mathrm{O} 1$ & $87.3(4)$ \\
\hline $\mathrm{O} 9-\mathrm{Mg} 1-\mathrm{O} 10$ & $92.8(4)$ & $\mathrm{O} 3-\mathrm{Mg} 2-\mathrm{O} 5$ & $87.6(4)$ \\
\hline $\mathrm{O} 7-\mathrm{Mg} 1-\mathrm{O} 10$ & $84.2(4)$ & $\mathrm{O} 6-\mathrm{Mg} 2-\mathrm{O} 5$ & $89.9(4)$ \\
\hline $\mathrm{O} 2^{\mathrm{i}}-\mathrm{Mg} 1-\mathrm{O} 10$ & $94.6(4)$ & $\mathrm{O} 2-\mathrm{Mg} 2-\mathrm{O} 5$ & $172.2(4)$ \\
\hline $\mathrm{O} 9-\mathrm{Mg} 1-\mathrm{O} 8$ & 89.5 (4) & $\mathrm{O} 1-\mathrm{Mg} 2-\mathrm{O} 5$ & $85.0(4)$ \\
\hline $\mathrm{O} 7-\mathrm{Mg} 1-\mathrm{O} 8$ & 87.7 (4) & $\mathrm{O} 3-\mathrm{Mg} 2-\mathrm{O} 4$ & $176.1(5)$ \\
\hline $\mathrm{O} 2^{\mathrm{i}}-\mathrm{Mg} 1-\mathrm{O} 8$ & $93.2(4)$ & $\mathrm{O} 6-\mathrm{Mg} 2-\mathrm{O} 4$ & $88.7(4)$ \\
\hline $\mathrm{O} 10-\mathrm{Mg} 1-\mathrm{O} 8$ & $171.6(4)$ & $\mathrm{O} 2-\mathrm{Mg} 2-\mathrm{O} 4$ & $85.8(4)$ \\
\hline $\mathrm{O} 9-\mathrm{Mg} 1-\mathrm{O} 6$ & $155.8(4)$ & $\mathrm{O} 1-\mathrm{Mg} 2-\mathrm{O} 4$ & $92.5(5)$ \\
\hline $\mathrm{O} 7-\mathrm{Mg} 1-\mathrm{O} 6$ & $112.5(4)$ & $\mathrm{O} 5-\mathrm{Mg} 2-\mathrm{O} 4$ & $94.4(4)$ \\
\hline $\mathrm{O} 2-\mathrm{Mg} 1-\mathrm{O} 6$ & $61.6(4)$ & $\mathrm{O} 3-\mathrm{Mg} 2-\mathrm{Mg} 1^{\mathrm{iii}}$ & $92.8(3)$ \\
\hline $\mathrm{O} 10-\mathrm{Mg} 1-\mathrm{O} 6$ & $89.6(4)$ & $\mathrm{O} 6-\mathrm{Mg} 2-\mathrm{Mg} 1^{\mathrm{iii}}$ & $71.4(3)$ \\
\hline $\mathrm{O} 8-\mathrm{Mg} 1-\mathrm{O} 6$ & $91.6(4)$ & $\mathrm{O} 2-\mathrm{Mg} 2-\mathrm{Mg} 1^{\mathrm{iii}}$ & $26.5(3)$ \\
\hline $\mathrm{O} 9-\mathrm{Mg} 1-\mathrm{C} 1^{\mathrm{iii}}$ & $124.7(4)$ & $\mathrm{O} 1-\mathrm{Mg} 2-\mathrm{Mg} 1^{\mathrm{iii}}$ & $113.8(3)$ \\
\hline $\mathrm{O} 7-\mathrm{Mg} 1-\mathrm{C} 1^{\mathrm{iii}}$ & $143.6(5)$ & $\mathrm{O} 5-\mathrm{Mg} 2-\mathrm{Mg} 1^{\mathrm{iii}}$ & $161.2(3)$ \\
\hline $\mathrm{O} 2^{\mathrm{i}}-\mathrm{Mg} 1-\mathrm{C} 1^{\mathrm{iii}}$ & $30.5(4)$ & $\mathrm{O} 4-\mathrm{Mg} 2-\mathrm{Mg} 1^{\mathrm{iii}}$ & $84.2(3)$ \\
\hline $\mathrm{O} 10-\mathrm{Mg} 1-\mathrm{C} 1^{\mathrm{iii}}$ & 93.4 (4) & $\mathrm{O} 9-\mathrm{C} 1-\mathrm{O} 2^{\mathrm{ii}}$ & $121.5(12)$ \\
\hline $\mathrm{O} 8-\mathrm{Mg} 1-\mathrm{C} 1^{\mathrm{iii}}$ & $92.0(4)$ & $\mathrm{O} 9-\mathrm{C} 1-\mathrm{O}^{\mathrm{i}}$ & $123.5(10)$ \\
\hline $\mathrm{O} 6-\mathrm{Mg} 1-\mathrm{C} 1^{\mathrm{iii}}$ & $31.1(4)$ & $\mathrm{O} 2^{\mathrm{ii}-\mathrm{C} 1-}-6^{\mathrm{i}}$ & $115.0(10)$ \\
\hline $\mathrm{O} 9-\mathrm{Mg} 1-\mathrm{Mg}^{\mathrm{i}}$ & $67.8(3)$ & $\mathrm{O} 9-\mathrm{C} 1-\mathrm{Mg} 1^{\mathrm{i}}$ & $175.9(10)$ \\
\hline $\mathrm{O} 7-\mathrm{Mg} 1-\mathrm{Mg} 2^{\mathrm{i}}$ & $159.4(3)$ & $\mathrm{O} 2^{\mathrm{ii}}-\mathrm{C} 1-\mathrm{Mg} 1^{\mathrm{i}}$ & $54.7(6)$ \\
\hline $\mathrm{O} 2^{\mathrm{i}}-\mathrm{Mg} 1-\mathrm{Mg} 2^{\mathrm{i}}$ & $26.4(2)$ & $\mathrm{O} 6{ }^{\mathrm{i}}-\mathrm{C} 1-\mathrm{Mg} 1^{\mathrm{i}}$ & $60.3(6)$ \\
\hline $\mathrm{O} 10-\mathrm{Mg} 1-\mathrm{Mg} 2^{\mathrm{i}}$ & $94.5(3)$ & $\mathrm{C}^{\mathrm{iv}}-\mathrm{O} 2-\mathrm{Mg} 2$ & $138.1(8)$ \\
\hline $\mathrm{O} 8-\mathrm{Mg} 1-\mathrm{Mg} 2^{\mathrm{i}}$ & $93.9(3)$ & $\mathrm{C} 1^{\mathrm{iv}}-\mathrm{O} 2-\mathrm{Mg} 1^{\mathrm{iii}}$ & $94.7(8)$ \\
\hline
\end{tabular}




$\begin{array}{llll}\mathrm{O} 6-\mathrm{Mg} 1-\mathrm{Mg} 2^{\mathrm{i}} & 88.0(3) & \mathrm{Mg} 2-\mathrm{O} 2-\mathrm{Mg} 1^{\mathrm{iii}} & 127.1(4) \\ \mathrm{C} 1^{1 \mathrm{ii}}-\mathrm{Mg} 1-\mathrm{Mg} 2^{\mathrm{i}} & 56.9(3) & \mathrm{C} 1^{\mathrm{iii}}-\mathrm{O} 6-\mathrm{Mg} 2 & 134.5(8) \\ \mathrm{O} 3-\mathrm{Mg} 2-\mathrm{O} 6 & 87.9(4) & \mathrm{C} 1^{\mathrm{iii}}-\mathrm{O} 6-\mathrm{Mg} 1 & 88.5(7) \\ \mathrm{O} 3-\mathrm{Mg} 2-\mathrm{O} 2 & 92.6(4) & \mathrm{Mg} 2-\mathrm{O} 6-\mathrm{Mg} 1 & 137.0(5) \\ \mathrm{O} 6-\mathrm{Mg} 2-\mathrm{O} 2 & 97.9(4) & \mathrm{C} 1-\mathrm{O} 9-\mathrm{Mg} 1 & 142.8(8)\end{array}$

Symmetry codes: (i) $x,-y, z-1 / 2$; (ii) $x, y, z-1$; (iii) $x,-y, z+1 / 2$; (iv) $x, y, z+1$.

Hydrogen-bond geometry $\left(\AA,{ }^{\circ}\right)$

\begin{tabular}{|c|c|c|c|c|}
\hline$D-\mathrm{H} \cdots A$ & $D-\mathrm{H}$ & $\mathrm{H} \cdots A$ & $D \cdots A$ & $D-\mathrm{H} \cdots A$ \\
\hline $\mathrm{O} 1-\mathrm{H} 1 A \cdots \mathrm{O}^{\text {iv }}$ & $0.82(3)$ & $1.94(6)$ & $2.688(14)$ & $153(13)$ \\
\hline $\mathrm{O} 1-\mathrm{H} 1 B \cdots \mathrm{Cl} 2^{\mathrm{iv}}$ & $0.82(3)$ & $2.38(4)$ & $3.186(11)$ & $167(12)$ \\
\hline $\mathrm{O} 3-\mathrm{H} 3 A \cdots \mathrm{Cl} 2^{\mathrm{v}}$ & $0.82(3)$ & $2.32(3)$ & $3.135(11)$ & $174(17)$ \\
\hline $\mathrm{O} 3-\mathrm{H} 3 B \cdots \mathrm{O} 4^{\mathrm{vi}}$ & $0.82(3)$ & $2.10(11)$ & $2.796(13)$ & $143(17)$ \\
\hline $\mathrm{O} 4-\mathrm{H} 4 A \cdots \mathrm{Cl} 11^{\mathrm{vii}}$ & $0.82(3)$ & $2.36(3)$ & $3.176(10)$ & $171(14)$ \\
\hline $\mathrm{O} 4-\mathrm{H} 4 B \cdots \mathrm{Cl} 1^{\mathrm{viii}}$ & $0.82(3)$ & $2.49(7)$ & $3.251(10)$ & $155(13)$ \\
\hline $\mathrm{O} 5-\mathrm{H} 5 A \cdots \mathrm{Cl} 2^{\text {viii }}$ & $0.82(3)$ & $2.45(7)$ & $3.222(11)$ & $157(16)$ \\
\hline $\mathrm{O} 5-\mathrm{H} 5 B^{\cdots}{ }^{\cdots} \mathrm{Cl} 1^{\mathrm{ix}}$ & $0.81(3)$ & $2.54(6)$ & $3.327(11)$ & $164(17)$ \\
\hline $\mathrm{O} 7-\mathrm{H} 7 A \cdots \mathrm{Cl} 2^{\text {viii }}$ & $0.82(3)$ & $2.42(6)$ & $3.212(11)$ & $163(16)$ \\
\hline $\mathrm{O} 7-\mathrm{H} 7 B \cdots \mathrm{C} 11^{\mathrm{x}}$ & $0.82(3)$ & $2.30(4)$ & $3.111(11)$ & $169(16)$ \\
\hline $\mathrm{O} 8-\mathrm{H} 8 A \cdots \mathrm{Cl} 2^{\mathrm{vi}}$ & $0.82(3)$ & $2.46(5)$ & $3.254(10)$ & $163(11)$ \\
\hline $\mathrm{O} 8-\mathrm{H} 8 B^{\cdots}{ }^{\cdots} \mathrm{Cl} 2^{v}$ & $0.82(3)$ & $2.41(3)$ & $3.233(10)$ & $178(11)$ \\
\hline $\mathrm{O} 10-\mathrm{H} 10 A \cdots \mathrm{Cl} 1^{\mathrm{vii}}$ & $0.82(3)$ & $2.34(5)$ & $3.146(10)$ & $166(15)$ \\
\hline $\mathrm{O} 10-\mathrm{H} 10 B \cdots \mathrm{Cl} 1^{\mathrm{xi}}$ & $0.82(3)$ & $2.67(7)$ & $3.424(10)$ & $154(12)$ \\
\hline
\end{tabular}

Symmetry codes: (iv) $x, y, z+1$; (v) $x+1 / 2, y-1 / 2, z+1$; (vi) $x+1 / 2,-y+1 / 2, z+1 / 2$; (vii) $x, y-1, z$; (viii) $x,-y+1, z+1 / 2$; (ix) $x+1 / 2,-y+3 / 2, z+1 / 2 ;$ (x) $x+1 / 2$, $y-1 / 2, z$; (xi) $x,-y+1, z-1 / 2$. 